\title{
Sociological and Psychological Factors on Prohibited Substances Abuse in Rehabilitation Centre of Medan City, Indonesia
}

Vita Camellia ${ }^{1 *}$, Fasihah Irfani Fitri ${ }^{2}$, Muhammad Surya Husada ${ }^{1}$, Dudy Aldiansyah ${ }^{3}$, Muhammad Ichwan ${ }^{4}$, Khairunnisa Khairunnisa ${ }^{4}$, Farah Diba Harahap ${ }^{5}$

${ }^{1}$ Department of Psychiatry, Faculty of Medicine, Universitas Sumatera Utara, Medan 20155, Indonesia; ${ }^{2}$ Department of Neurology, Faculty of Medicine, Universitas Sumatera Utara, Medan 20155, Indonesia; ${ }^{3}$ Department of Obstetrics and Gynaecology, Faculty of Medicine, Universitas Sumatera Utara, Medan 20155, Indonesia; ${ }^{4}$ Department of Pharmacology, Faculty of Medicine, Universitas Sumatera Utara, Medan 20155, Indonesia; ${ }^{5}$ Department of Health, STIKES Nurliana, Medan 20237, Indonesia

Citation: Camellia V, Fitri FI, Husada MS, Aldiansyah D Ichwan M, Khairunnisa K, Harahap FD. Sociological an Rehabilitation Centre of Medan City, Indonesia Open Access Maced J Med Sci. 2019 Dec 15; 7(23):4137-4142. https://doi.org/10.3889/oamjms.2019.611

Keywords: Social and Psychological Factor; Prohibited Substances; Rehabilitation

*Correspondence: Vita Camellia Department *Correspondence: Vita Camellia. Department Utara, Medan 20155, Indonesia. E-mail vita.camellia@usu.ac.id

Received: 23-Apr-2019. Revised: 16-Sep-2019; Accepted: 17-Sep-2019; Online first: 14-Oct-2019 Copyright: ๑ 2019 Vita Camellia, Fasihah Irfani Fitri, Muhammad Surya Husada, Dudy Aldiansyah, Muhamma This is an open-access article distributed under the term of the Creative Commons Attribution-NonCommercial 4.0 International License (CC BY-NC 4.0)

Funding: This research did not receive any financia support

Competing Interests: The authors have declared that no competing interests exist

\begin{abstract}
INTRODUCTION: Prohibited substances issue and their abuse have become a scourge for people in Indonesia. This situation creates concern for every level of society since this is very influential to damage and can even
\end{abstract} eliminate generations at a later time.

AIM: This study aims to determine the characteristics of age, education, psychological and social problems related to substance dependence experienced by individuals with substance disorders who undergo rehabilitation in Medan, Indonesia.

METHODS: This study is a cross-sectional analytic, in which the sample of this study was individuals who underwent rehabilitation in the Rehabilitation Center in Medan City who fulfilled the inclusion and exclusion criteria. A structured interview was carried out with the MINI ICD-10 on part M. disorders related to psychoactive substances. Furthermore, to see the level of dependence, WHO ASSIST questionnaire (The Alcohol, Smoking and Substance Involvement Screening Test) was used.

RESULTS: This study discovered that subjects with age above 21 years were the most dominant of the prohibited substance users group as many as 87 people $(69 \%)$, Batak tribe with 73 people $(57.9 \%)$, residence originating from outside the city with 70 people $(55.6 \%)$, Unmarried with 87 people $(70.2 \%)$, education level is medium (junio high school) with 117 people (92 $9 \%$ ) and work as many as 77 people $(61.1 \%)$. The study also found that the most dominant number of prohibited substances users were single users of methamphetamine and a combination of two substances, each of which was 49 people $(38.9 \%)$. There is no relationship between social factors and patterns of prohibited substance use. Also, the most dominant users of prohibited substances who undergo rehabilitation are those based on family and police (involuntary admission). Finally, as many as 70 people used methamphetamine require intensive intervention.

CONCLUSION: This study shows that social and demographic factors are not related to the pattern of prohibited substance use.

\section{Introduction}

In 1970, the number of illegal substance users in Indonesia was estimated at 130,000 . But by the end of 2000 , the number had reached 2 million. This means that within 30 years, the number of prohibited substances users has increased by 150 times or $15,000 \%$ [1]. While according to National Drugs Agency of Indonesia (BNN), prohibited substance users in Indonesia until November 2015 has reached the number of 5.9 million people [2].
Indonesia's role has now even increased to become a producer. Later, prohibited substances made in Indonesia were then exported abroad; making Indonesia has become an exporter of prohibited substances. From the transit area, Indonesia became the market, producer, and finally exporter of prohibited substances [1].

The use of prohibited substances or drugs (Narcotics, psychotropic substances and other addictive substances) are complex problems and have become a concern for the government because they are related to the next generation of the nation, 
and this has been stated in Indonesian legislation. Law Number 35 of 2009 concerning Narcotics stipulates that planters, distributors, producers and users are threatened with criminal sanctions [3].

Based on National Narcotics Agency (BNN) data in 2011, the age range of people who tend to use the prohibited substance is $10-59$ years, including the age group of $10-19$ years (2.27\%), age group 20-29 years $(4.41 \%)$, age group $30-39$ years $(1.08 \%)$, and groups above 40 years (1.06\%). Abuse of prohibited substances was reported to be higher in the group of workers $(70 \%)$ compared to groups not working (22\%) [2].

According to the BNN data in 2016, the prevalence of prohibited substance abusers is measured by referring to two periods of time, that is, once used only once and the last year used. The prevalence rate has been used according to the study location at the district/city level; it is seen that in 2006, it was relatively not much different $(8.1 \%)$. However, from 2009 to 2016, the prevalence rates have been used tend to be higher in cities than districts. While the prevalence of one year use in district locations tends to decrease in 4 surveys from $5.5 \%$ (2006) to $1.6 \%(2016)$, but not in the city.

According to the BNN report, the number of people who have used narcotics in the population is estimated to be $2.4 \%$ with men far greater than women in 2011, the prevalence of prohibited substance abuse in Indonesia is around $2.2 \%$ or around 3.8-4.2 million people. The rate of prohibited substance dependence refers to the use of prohibited substances in the past year divided into 4 categories, namely prohibited substance abuse, try to use, regularly use individuals with non-injectable substance disorders and individuals with injectable substance disorders [2]. In 2016, the proportion of trial use was the highest, which was $85 \%$ of the highest of 4 surveys, while the lowest was $54 \%$ in 2006 . The next largest group was regular use, individuals with noninjecting substances and the lowest individuals with injectable substances, respectively.

The abuse of prohibited substances according to the Law of the Republic of Indonesia number 35 of 2009 is categorised as activity of people who use narcotics without rights or against the law. On the other hand, narcotics dependence is a condition that is characterised by the urge to use narcotics continuously with increasing doses to produce the same effect if the use is reduced and or suddenly stopped causing typical physical and psychological symptoms [3]. The use of prohibited substances can cause physical and psychological problems, including the impact of continued use of prohibited substances, can damage kidney and liver function, heart and stroke, malnutrition, tuberculosis infection (TBC), transmission of HIV/AIDS with prohibited substances syringes and psychological problems can cause severe psychosis, depression and anxiety or comorbid conditions. And the most fatal impact is that it can cause death from an overdose [4], [5], [6], [7].

Chang et al., (2005) stated that the management approach for individuals with substance disorders including detoxification, alcoholic anonymous, therapeutic community, methadone maintenance, use of buprenorphine, naltrexone use, group therapy in outpatients, tissue therapy, the establishment of rehabilitation centres, and prevention of recurrence [8].

According to Indonesian Law No. 5, article 38 [3], rehabilitation for psychotropic users who suffer from dependency syndrome is intended to restore their physical, mental and social abilities. And in Article 39 paragraphs 1 to 3 states, rehabilitation for psychotropic users who suffer from dependency syndrome is carried out at rehabilitation facilities organised by the government/community, rehabilitation, as referred to in paragraph 1 , is medical rehabilitation and social rehabilitation, implementation of medical rehabilitation facilities as referred to in paragraphs 1 and 2 can only be done based on permission from the Minister.

Whereas according to Indonesian Law No. 22, chapter VII, article 48 paragraph 1 and 2 states [3], treatment and/or treatment of narcotics addicts is carried out through rehabilitation facilities, and rehabilitation includes medical rehabilitation and social rehabilitation. In article 49 paragraph 1 to 3 states, medical rehabilitation of individuals with narcotics disorders is carried out in hospitals designated by the Minister of Health, or based on the approval of the health minister, certain rehabilitation institutions organised by the public can carry out medical rehabilitation of individuals with narcotic disorders, other than treatment and/or care through medical rehabilitation, the process of healing individuals with narcotics disorders can be carried out by the community through religious and traditional approaches. Article 50 states that social rehabilitation of individuals with narcotics disorders is carried out at social rehabilitation institutions appointed by the Minister of Social Affairs.

The guidelines for administering drug abuse rehabilitation services are regulated by the decision of the Minister of Health of the Republic of Indonesia No. 996/MENKES/SK/VII/2002 [9].

The provision of Article 54 of the Narcotics Law, which states that individuals with prohibited substances and victims of illicit substance abuse must undergo medical and social rehabilitation. Even though there are rehabilitation laws, only a few receive services from health workers and receive rehabilitation.

While the 3rd Guidelines for Diagnostic Classification of Mental Disorders in Indonesia (PPDGJ III) states that the impact of illicit substance use can be categorised as Mental Disorders and 
Behavior due to the Use of Psychoactive Substances so that rehabilitation needs involving various elements including psychiatrists, doctors related to individual medical conditions with substance disorders, psychologists, social workers, vocational experts and also law.

Therefore, based on the background described, this study aims to determine the characteristics of age, education, and personality factors, psychological problems related to prohibited substance abuse by individuals with substance disorders who undergo rehabilitation in the city of Medan. This research has never been done before in the city of Medan. Given that in Medan City, the problem of preventing prohibited substances in rehabilitation centres is still based on social treatment, not comprehensive and is separated from medical and social rehabilitation. So, an effort is needed to analyse social, psychological, and dependency factors in individuals with substance disorders in rehabilitation centre of Medan city.

\section{Methods}

This study was a descriptive study with a cross-sectional approach in individuals with substance disorders who underwent rehabilitation in a rehabilitation centre in the city of Medan. The research was located in a rehabilitation centre in Medan City, where ten rehabilitation centers will be the place of research. However, only five centres agreed to participate in this study. Moreover, this study was performed for one year. The sample of this study were individuals with prohibited substance disorders who underwent rehabilitation in Rehabilitation Homes in Medan City who met the inclusion and exclusion criteria.

Inclusion Criteria: 1. Willing to be a research subject; 2. Urine examination shows negative results for all substances (marijuana, amphetamine/methamphetamine, opioids, benzodiazepines); 3 . Ages of 15-55 years old; 4 . Cooperative; and 5. Detoxification has finished.

Exclusion Criteria: 1. Cannot read and write and 2. Mental retardation.

Estimation of sample size: quota sampling, that is, all individuals with substance disorders undergoing rehabilitation in 5 rehabilitation centres in the city of Medan was found to meet criteria for as much as 126 people.

\section{Procedure}

Individuals who are using prohibited substances have fulfilled the inclusion and exclusion criteria to be the subjects of the study where the subject will be subjected to a urine test, to ensure that the subject has abstained and completed detoxification (has undergone one month's social rehabilitation). Then, structured interviews with MINI ICD-10 in section $\mathrm{M}$ disorders related to psychoactive substances were performed. Moreover, to see the demographic characteristics and environmental background and family factors, a questionnaire (WHO ASSIST) was filled in by the subject.

WHO ASSIST questionnaire (The Alcohol, Smoking and Substance Involvement Screening Test) was used to observe the history of substance use, the type of substance prohibited, and the degree of dependence on prohibited substances.

Furthermore, the WHO ASSIST can determine the type of intervention used. If the WHO ASSIST result scores of $0-3$, it means that intervention is not needed. While a score of 4-26 requires a short intervention and a score of more than 27 requires more intensive treatment.

\section{Table 1: Study Population}

\begin{tabular}{|c|c|}
\hline $\begin{array}{l}\text { The social aspect of individuals with prohibited substance } \\
\text { abuse }\end{array}$ & $n(\%)$ \\
\hline \multicolumn{2}{|l|}{ Age (year) } \\
\hline$<21$ & $39(31 \%)$ \\
\hline$>21$ & $87(69 \%)$ \\
\hline \multicolumn{2}{|l|}{ Ethnic Group } \\
\hline Bataknese & $73(57,9 \%)$ \\
\hline Acehnese & $17(13.5 \%)$ \\
\hline Javanese & $23(18.3 \%)$ \\
\hline Minangnese & $4(3.2 \%)$ \\
\hline Melayunese & $6(4.8 \%)$ \\
\hline Others & $3(2.4 \%)$ \\
\hline \multicolumn{2}{|l|}{ Domicile } \\
\hline City & $56(44.4 \%)$ \\
\hline Outside the city & $70(55.6 \%)$ \\
\hline \multicolumn{2}{|l|}{ Marital Status } \\
\hline Unmarried & $87(70.2 \%)$ \\
\hline Married & $30(24.2 \%)$ \\
\hline Divorced & $7(5.6 \%)$ \\
\hline \multicolumn{2}{|l|}{ Educational Background } \\
\hline Elementary & $2(1.6 \%)$ \\
\hline Junior-Senior High School & $117(92.9 \%)$ \\
\hline Higher Education & $7(5.6 \%)$ \\
\hline \multicolumn{2}{|l|}{ Work Status } \\
\hline Work & $77(61.1 \%)$ \\
\hline Unemployed & $49(38.9 \%)$ \\
\hline Psychological aspects of substance-seeking behaviour & $\mathrm{n}(\%)$ \\
\hline Influence of friends & $31(24.6 \%)$ \\
\hline Disappointed & $18(14.3 \%)$ \\
\hline Enhancing work performance & $21(16.7 \%)$ \\
\hline Curious & $22(17.5 \%)$ \\
\hline Depressed & $3(2.4 \%)$ \\
\hline No answer & $31(24.6 \%)$ \\
\hline Information related to rehabilitation & $\mathrm{n}(\%)$ \\
\hline \multicolumn{2}{|l|}{ Reason to carry out rehabilitation } \\
\hline Self-willingness & $56(44 \%)$ \\
\hline Family or police recommendation & $62(49 \%)$ \\
\hline No answer & $8(6.3 \%)$ \\
\hline \multicolumn{2}{|l|}{ Rehabilitation frequency } \\
\hline 1 & $87(69.0 \%)$ \\
\hline$>1$ & 39 (31.0\%) \\
\hline \multicolumn{2}{|l|}{ Rehabilitation duration } \\
\hline$>1-6$ months & $84(66.7 \%)$ \\
\hline$>6$ month & $42(33.3 \%)$ \\
\hline \multicolumn{2}{|l|}{ Previous rehabilitation experience } \\
\hline Yes & $12(9.5 \%)$ \\
\hline No & $114(90.5 \%)$ \\
\hline \multicolumn{2}{|l|}{ Rehabilitation treatment satisfactory } \\
\hline Very satisfied & $26(20.6 \%)$ \\
\hline Satisfied & $36(28.6 \%)$ \\
\hline Quite satisfied & $35(27.8 \%)$ \\
\hline Less satisfied & $18(14.3 \%)$ \\
\hline Not satisfied & $11(8.7 \%)$ \\
\hline The prohibited substance used use pattern & $\mathrm{n}(\%)$ \\
\hline \multicolumn{2}{|l|}{ Amphetamine } \\
\hline Single (Amphetamine use) & $49(38.9 \%)$ \\
\hline 2 substances combination & $49(38.9 \%)$ \\
\hline$>2$ substances & $28(22.2 \%)$ \\
\hline
\end{tabular}


Demographic data and social factors were obtained from interviews regarding age, ethnicity, place of residence, education level, marital status, employment.

\section{Results}

The study was conducted in five social rehabilitation centres with 126 subjects. All subjects who met the criteria were men who had a history of prohibited substance use in one year were willing to take part in this study and had undergone rehabilitation for one month and were interviewed with questionnaires.

In the study population, the most dominant was the age group above 21 to abuse the prohibited substance for as many as 87 people (69\%), Batak tribe with 73 people $(57.9 \%)$, residence originating from outside the city of 70 people $(55.6 \%)$, marital status of unmarried with 87 people $(70.2 \%)$, the level of education is junior-senior high school with 117 people (92.9\%) and working as many as 77 people $(61.1 \%)$. It is found that the influence of friends is dominant for an individual to use prohibited substances with 31 people (24.6\%). 62 prohibited substance abusers have undergone rehabilitation, dominated by family or police recommendation. Also, 87 people $(69.0 \%)$ was recorded for having rehabilitation for the first time, and 84 people (66.7\%) dominate the rehabilitation period for more than 1-6 month. They expressed the rehabilitation services with a satisfaction level of satisfied with 36 people (28.6\%). It can be seen that the most dominant number of amphetamine users is the single user and the combination of two substances, each of which is 49 people (38.9\%). The only type of prohibited substance used is dominant methamphetamine and users of a combination of two or more substances, besides methamphetamine, they use cannabis, ecstasy and opioids.

In Table 2, the highest daily cigarette use rate of individuals with prohibited substance use is 11-20 cigarettes/ day, consumed by 73 people (57.9\%).

Table 2: Cigarettes use rate

\begin{tabular}{lc}
\hline Cigarette use & $\mathrm{n}(\%)$ \\
\hline Rate of smoking & $23(18.3 \%)$ \\
$1-10$ cigarettes/day & $73(57.9 \%)$ \\
$11-20$ cigarettes/day & $14(11.1 \%)$ \\
$21-30$ cigarettes/day & $16(14.41 \%)$ \\
$>31$ cigarettes/day & \\
\hline
\end{tabular}

Overall, Table 3 describes that there is no significant relationship between the prohibited substance used patterns with the demographic characteristics of the research subjects.
Table 3: The relationship between demographic characteristics and the prohibited substance use pattern

\begin{tabular}{|c|c|c|c|c|}
\hline \multirow{2}{*}{$\begin{array}{l}\text { Demographic } \\
\text { Characteristics }\end{array}$} & \multicolumn{3}{|c|}{ Number of Prohibited Substances used } & \multirow{3}{*}{$P$} \\
\hline & Single & Combination & $>2$ type & \\
\hline \multicolumn{4}{|l|}{ Age } & \\
\hline Age $<21$ years old & 13 & 15 & 11 & \multirow[t]{2}{*}{0.506} \\
\hline Age $>21$ years old & 36 & 34 & 17 & \\
\hline \multicolumn{5}{|l|}{ Ethnics Group } \\
\hline Bataknese & 26 & 28 & 19 & \multirow{6}{*}{0.600} \\
\hline Acehnese & 9 & 7 & 1 & \\
\hline Javanese & 10 & 7 & 6 & \\
\hline Minangnese & 1 & 2 & 1 & \\
\hline Melayunese & 3 & 3 & 0 & \\
\hline Others & 0 & 2 & 1 & \\
\hline \multicolumn{5}{|l|}{ Domicile } \\
\hline City & 22 & 19 & 15 & \multirow[t]{2}{*}{0.452} \\
\hline Outside the city & 27 & 30 & 13 & \\
\hline \multicolumn{5}{|l|}{ Marital Status } \\
\hline Unmarried & 28 & 35 & 24 & \multirow{3}{*}{0.103} \\
\hline Married & 17 & 10 & 3 & \\
\hline Divorced & 4 & 2 & 1 & \\
\hline \multicolumn{5}{|l|}{ Educational } \\
\hline Background & & & & \multirow{4}{*}{0.360} \\
\hline Elementary & 0 & 2 & 0 & \\
\hline $\begin{array}{l}\text { Junior-Senior High } \\
\text { School }\end{array}$ & 47 & 43 & 27 & \\
\hline Higher Education & 2 & 4 & 1 & \\
\hline \multicolumn{5}{|l|}{ Work Status } \\
\hline Work & 32 & 28 & 17 & \multirow{2}{*}{0.708} \\
\hline Unemployed & 17 & 21 & 11 & \\
\hline
\end{tabular}

In Table 4, the dependency level according to WHO Assist and the type of intervention needed according to the type of prohibited substance used is dominated by methamphetamine for 70 people, which shows WHO Assist score above 27.

Table 4: The addiction level according to WHO ASSIST and intervention type needed towards the prohibited substances used

\begin{tabular}{lccc}
\hline $\begin{array}{l}\text { Prohibited Substances Used } \\
\text { in Last 3 Months before }\end{array}$ & $\begin{array}{c}\text { Intervention Type } \\
\text { No Intervention } \\
\text { Treated in Rehabilitation }\end{array}$ & $\begin{array}{c}\text { Short Intervention } \\
(4-26)\end{array}$ & $\begin{array}{c}\text { Intensive } \\
\text { Medication } \\
(+27)\end{array}$ \\
Center & 3 people & 86 people & 37 people \\
Tobacco & 60 people & 41 people & 25 people \\
Alcohol & 53 people & 51 people & 22 people \\
Cannabis & 117 people & 7 people & 2 people \\
Cocaine & 11 people & 45 people & 70 people \\
Amphetamine/Stimulants & 120 people & 5 people & 1 people \\
Inhalation & 123 people & 3 people & 0 \\
Sedative & 126 people & 0 & 0 \\
Hallucinogens & 124 people & 1 people & 1 people \\
Opioid & 125 people & 1 people & 0 \\
Other substances & & &
\end{tabular}

\section{Discussion}

In this study, it was found that several demographic characteristics that dominate the prohibited substance abuse, such as adult age, Bataknese, residence originating from outside the city, unmarried, junior-senior high school educational background and working. Previous research has found that educational and employment achievements could be affected by prohibited substance abuse [10]. The use of prohibited substances can result in poor school performance and drop out, lower education status and low income. This is consistent with BNN data that the age of prohibited substance abuse is 1059 years, which is dominated by the age group of 20 29 years. Those who abuse prohibited substances are also dominated by those who work. This result differs 
according to Teesson \& Newton (2015), stated that methamphetamine dependence in the United States relates to a younger age, the onset of use of younger, whites, residing in western and southern America [11]. While according to Rawson (2013), it was found that as many as 52 million people aged $15-64$ years had used amphetamine stimulants [12].

In this study, the highest reason to start using prohibited substances was to follow friends. This was in line with Sattah et al., (2001), discovered that methamphetamine use was strongly correlated with other substance use, sexual activity, group pressure, methamphetamine-positive behaviour and the absence of close family [13]. While other previous findings found that people will continue to use methamphetamine because of the reward effect of euphoria, decreased fatigue and hunger, increased energy, sexual drive and self-confidence [14], [15], [16].

Furthermore, this study found that the most dominant number of amphetamine users was single users and a combination of two substances. Surprisingly, there is no correlation between age, ethnicity, domicile, marital status, education level and occupation with the pattern of amphetamine use. This study is in line with Sattah et al., (2001), stating that methamphetamine use is not associated with age, parental separation situation or patient's life situation, but Sattah study sample was only adolescents aged 15-21 years [13].

The prohibited substance users were smokers with moderate to severe smoking who were smoking more than 10 cigarettes/day. Scheuermann et al. (2015) categorised that the level of cigarette use was mild $=1-10$ cigarettes/day, moderate to heavy $=$ more than 11 cigarettes/day [17]. Tobacco and alcohol are often referred to as "drugs gateway" among the first substances consumed by adolescents. This is also influenced by their availability in line with sociocultural and biological factors. Many studies said that smokers in adolescents tend to be a matter of substance use and law in their 20s [18]. A populationbased study discovered that behavioural problems, smoking and child sexual abuse were predictors from the start to use amphetamine and became amphetamine abuser [22]. The use of cigarette products is a major cause of death and is a major health problem. Regular smoking is a risk factor for long-term health problems such as high blood pressure, heart disease, chronic obstructive respiratory disease.

According to Opsal et al., (2013), individuals with substance use disorder refuse treatment because they deny the disturbances they have, feelings of helplessness or negative attitudes toward treatment [19]. In many countries, individuals with substance use disorders who undergo rehabilitation, not on their own are controversial choices when treatment of their desires shows no success. Moreover, in 2001, it turned out that 73 out of 90 countries in the world had provided some form of commitment that must be obeyed in-law/computational commitment (acute or rehabilitation) which was motivated by the aim of protecting legally capable individuals who hurt themselves and vulnerable situations due to substance use. While laws in Indonesia protect those users of prohibited substances who experience dependency must receive medical and social rehabilitation. However, most illegal substance users do not undergo medical rehabilitation so that the treatment undertaken by users of prohibited substances is not comprehensive and integrated.

Finally, this study discovered that 70 people using methamphetamine need intensive intervention. Intensive interventions usually consist of several sessions which include substance education, substance rejection skills, relaxation training, and exploration of motivation to change substance use behaviour, cognitive therapy, problem-solving skills, management craving and planning release to the community to help patients from relapsing conditions [20]. While the five rehabilitation centres used Therapeutic Communities and one of the rehabilitation centre is using the Alcoholic Anonymous method.

Based on the research findings, it can be concluded that the prohibited substances abuse can lead to the damage and effect to several demographic statuses. However, a significant relationship between the social and psychological factor and prohibited substances used pattern was not found.

\section{Acknowledgement}

Authors would like to acknowledge the Rehabilitation Center in Medan City, Indonesia, for facilitating the research.

\section{Ethical Aspects}

Authors declare that ethical clearance has been obtained towards this research, regulated by Universitas Sumatera Utara, Indonesia.

\section{References}

1. Partodiharjo S. Kenali narkoba dan musuhi penyalahgunaannya. Jakarta: Penerbit Esensi, 2008.

2. Perka BNN. RI Nomor 2 Tahun 2011 tentang Tata Cara 
Penanganan Tersangka atau Terdakwa Penyalah Guna, Korban Penyalahgunaan, dan Pecandu Narkotika, 2011.

3. Undang-Undang Nomor 35 Tahun 2009 tentang Narkotika (Lembaran Negara Republik Indonesia Tahun 2009 Nomor 143. Tambahan Lembaran Negara Republik Indonesia Tahun, 2009 Nomor 5062, selanjutnya disebut UU Narkotika.

4. Berg CJ, Schauer GL. Results of a feasibility and acceptability trial of an online smoking cessation program targeting young adult nondaily smokers. Journal of Environmental and Public Health. 2012; 2012:248541. https://doi.org/10.1155/2012/248541 PMid:22570666 PMCid:PMC3335250

5. Bronars CA, Faseru B, Krebill R, Mayo MS, Snow TM, Okuyemi $\mathrm{KS}$, Cox LS, et al. Examining smoking dependence motives among African American light smokers. Journal of Smoking Cessation. 2014:1-8. https://doi.org/10.1017/jsc.2014.7 PMid:26557184 PMCid:PMC4635476

6. Piper ME, Piasecki TM, Federman EB, Bolt DM, Smith SS, Fiore MC, Baker TB. A multiple motives approach to tobacco dependence: The Wisconsin inventory of smoking dependence motives (WISDM-68). Journal of Consulting and Clinical Psychology. 2004; 72(2):139-154. https://doi.org/10.1037/0022006X.72.2.139 PMid: 15065950

7. Teeson M, Mewton L. Epidemiology of Addiction. In Galanter M, Kleber HD, Brady KT Eds. Textbook of Substance Abuse Treatment. Washington DC. American Psychiatric Publishing, 2015:47-57.

https://doi.org/10.1176/appi.books.9781615370030.mg03

8. Chang GC, et. Treatment approaches. In: Lowinson JH, Ruiz P, Millman RB, Langrod JG, eds. Substance abuse a comprehensive textbook. 4th ed. Philadelphia: Lippincott Williams \& Wilkins, 2015:579-804.

9. Depkes RI 2002. Modul Pelatihan teknis medis penanggulangan penyalahgunaan NAPZA.Depkes Dirjen Bina Kesehatan Masyarakat .Jakarta

10. Reitzel LR, Costello TJ, Mazas CA, Vidrine JI, Businelle MS Kendzor DE, Wetter DW, et al. Low-level smoking among Spanishspeaking Latino smokers: Relationships with demographics,

tobacco dependence, withdrawal, and cessation. Nicotine \&

Tobacco Research. 2009; 11(2):178-184.

https://doi.org/10.1093/ntr/ntn021 PMid:19246627

PMCid:PMC2658909

11. Galanter M, Kleber HD, Brady K, editors. The American Psychiatric Publishing textbook of substance abuse treatment. American Psychiatric Pub, 2014. https://doi.org/10.1176/appi.books. 9781615370030

12. Rawson RA. Current research on the epidemiology, medical and psychiatric effect, and treatment of mehtamphetamin use. Journal of Food and Drug Analysis. 2013; 21:77-81. https://doi.org/10.1016/.j.fda.2013.09.039 PMid:25214749 PMCid:PMC4158843
13. Sattah MV, Supawitkul S, Dondero TJ, Kilmax PH, Young NL, et al. Prevalence of and risk factors for methamphetamine use in northern Thai youth: results of an audio-computer-assisted selfinterviewing survey with urine testing. Addiction. 2002; 97(7):801808. https://doi.org/10.1046/j.1360-0443.2002.00131.x PMid:12133118

14. Shiffman S, Dunbar MS, Scholl SM, Tindle HA. Smoking motives of daily and non-daily smokers: A profile analysis. Drug and Alcohol Dependence. 2012; 126(3):362-368. https://doi.org/10.1016/i.drugalcdep.2012.05.037 PMid:22784601 PMCid:PMC3970262

15. Shiffman S, Ferguson SG, Dunbar MS, Scholl SM. Tobacco dependence among intermittent smokers. Nicotine \& Tobacco Research. 2012; 14(11):1372-1381.

https://doi.org/10.1093/ntr/nts097 PMid:22529224 PMCid:PMC3482012

16. Smith SS, Piper ME, Bolt DM, Fiore MC, Wetter DW, Cinciripini PM, Baker TB. Development of the brief Wisconsin inventory of smoking dependence motives. Nicotine \& Tobacco Research. 2010; 12(5):489-499. https://doi.org/10.1093/ntr/ntq032 PMid:20231242 PMCid:PMC2861888

17. Scheuermann TS, Nollen NL, Cox LS, Reitzel LR, Berg CJ, et al. Smoking dependence acros the levels of cigarette smoking in a multiethnic sample. Addictive Behaviors. 2015; 43:1-6. https://doi.org/10.1016/j.addbeh.2014.11.017 PMid:25498030 PMCid:PMC4305016

18. Myers MG, Kelly JF. Cigarette smoking among adolescents with alcohol and other drug use problems. Alcohol Research Health. 2006; 29(3):221-227.

19. Opsal A, Kristensen O, Larsen TK, Syversen Gro, Rudshaug BEA, Gerdner A, Clausen T. Factors associated with involuntary admissions among patients with substance use disorders and comorbidity: a cross-sectional study, BMC Health Services Research. 2013; 13:57. https://doi.org/10.1186/1472-6963-13-57 PMid:23399599 PMCid:PMC3575229

20. World Health Organization. Clinical Guideline for withdrawal management and treatment of drug dependence in closed settings, 2009.

21. Humeniuk R, Henry-Edwards S, Ali R, Poznyak V, Monteiro MG, World Health Organization. The Alcohol, Smoking and Substance Involvement Screening Test (ASSIST): manual for use in primary care.

22. Hayatbakhsh MR, Najman JM, Bor W, Williams GM. Predictors of young adults' amphetamine use and disorders: A prospective study. Drug and Alcohol Review. 2009; 28(3):275-83.

https://doi.org/10.1111/j.1465-3362.2009.00032.x PMid:21462412 